\author{
ADRIAN UlJASZ \\ Uniwersytet Rzeszowski \\ Instytut Historii
}

\title{
JóZEF GRYCZ (1890-1954). BIBLIOTEKARZ I BIBLIOLOG
}

Józef Grycz to jeden z najwybitniejszych polskich bibliotekarzy i organizatorów bibliotek, a zarazem zasłużony bibliolog. Należał do osób łączących pracę bibliotekarską z refleksją teoretyczną w dziedzinie księgoznawstwa. Żył w tej samej epoce co Jan Muszkowski i podobnie jak on miał wkład do praktycznego rozwoju zawodów związanych z książką oraz do bibliologii jako nauki. Drogi obu się spotykały, o czym będzie mowa w prezentowanym artykule.

Grycz pochodził z ziemi cieszyńskiej. Urodził się 11 grudnia 1890 roku w Zebrzydowicach ${ }^{1}$, niespełna dziewięć lat po Muszkowskim, który przyszedł na świat 10 kwietnia 1882 roku w Warszawie ${ }^{2}$. Ojciec Grycza pracował w Zebrzydowicach jako nauczyciel ludowy, nazywany w śląskiej gwarze „rechtorem”. Rodzice Józefa mieli pochodzenie robotnicze, rzemieślnicze i chłopskie. Dziadek ze strony ojca był cieślą, ojciec matki małorolnym chłopem, a stryjowie górnikami. Przyszły bibliotekarz uzyskał maturę w Gim-

${ }^{1}$ H. Więckowska, Grycz Józef (11 XII 1890 Zebrzydowice - 23 X 1954 Warszawa) [w:] Słownik pracowników książki polskiej, Warszawa-Łódź 1972, s. 300; H. Więckowska, I. Treichel, Grycz Józef (1890-1954) [w:] Polski słownik biograficzny (dalej: PSB), t. IX, Wrocław [i in.] 1960-1961, s. 69.

${ }^{2}$ H. Więckowska, Muszkowski Jan (10 IV 1882 Warszawa - 29 I 1953 Łódź) [w:] Słownik pracowników..., s. 615; Taż, Muszkowski Jan (1882-1953) [w:] PSB, t. XXII/2, z. 93, Wrocław [i in.] 1977, s. 298. 
nazjum Polskim w Cieszynie. Od 1909 roku studiował filologię germańską i klasyczną na Uniwersytecie Jagiellońskim. W latach 1913-1914 kontynuował edukację uniwersytecką w Berlinie, a później w Wiedniu. W 1915 uzyskał na uniwersytecie wiedeńskim tytuł doktora filozofii. Tytuł dysertacji brzmiał: Heinrich von Kleist Penthesilea ${ }^{3}$. Jako student zapoznał się z licznymi, dobrze zorganizowanymi bibliotekami zagranicznymi, co obudziło w nim chęć do pracy w zawodzie bibliotekarza ${ }^{4}$.

Wiosną 1916 roku starał się o zatrudnienie w Bibliotece Jagiellońskiej, niestety bezskutecznie. Pracę w książnicy rozpoczął 15 listopada, ale jako wolontariusz. Wolontariat trwał osiem miesięcy. Grycza wprowadzali do zawodu dwaj kustosze: Józef Korzeniowski i późniejszy dyrektor „Jagiellonki” Edward Kuntze ${ }^{5}$.

Od 15 lipca 1917 Grycz pracował w krakowskiej księgarni wydawniczej S. A. Krzyżanowskiego. Został tam przyjęty na praktykanta, aby stać się później, po przejściu kolejnych stopni zawodu księgarza, zastępcą szefa firmy. Zanim otrzymał tę funkcję pracował jako sprzedawca, w magazynach, a także w działach zagranicznym i wydawniczym. W 1920 roku nie przyjął proponowanego stanowiska w bibliotece Uniwersytetu Lwowskiego. Kupił za to Księgarnię Podhalańską Antoniego Stanisława Zembatego w Zakopanem. Po dwóch latach sprzedał ją i podjął pracę bibliotekarską w Bibliotece Jagiellońskiej. Po objęciu kierownictwa czytelni głównej dokonał reorganizacji księgozbioru podręcznego ${ }^{6}$.

W 1924 roku zwrócił uwagę na łamach czasopisma „Exlibris” na potrzebę skodyfikowania zasad katalogowania zbiorów w polskich bibliotekach. Przekonywał, że w tym celu powinna zostać powołana komisja, złożona

${ }^{3}$ H. Więckowska, Grycz Józef..., s. 300; H. Więckowska, I. Treichel, Grycz Józef..., s. 69; B. Horodyski, Józef Grycz, Warszawa 1955, s. 3 (odbitka z czasopisma „Przegląd Biblioteczny”). W 1961 roku artykuł Horodyskiego został przedrukowany w księdze pamiątkowej poświęconej Gryczowi, zob.: B. Horodyski, Józef Grycz [w:] Z zagadnień teorii i praktyki bibliotekarskiej. Studia poświęcone pamięci Józefa Grycza, Warszawa, Wrocław, Kraków 1961, s. 22-54. Zob. też publikację tego artykułu w „Przeglądzie Bibliotecznym”: B. Horodyski, Józef Grycz, „Przegląd Biblioteczny" 1955, R. 23, z. 1, s. 1-40; Materialy do stownika bio-bibliograficznego bibliotekarzy polskich i obcych (hasło Grycz Józef), „Biuletyn Biblioteki Publicznej Miasta Stołecznego Warszawy" 1933/34, R. 5, nr 9-10, s. 31.

${ }^{4}$ W. Pociecha, Józef Grycz. Człowiek i dzieło, „Pamiętnik Biblioteki Kórnickiej” 1955, z. 5, s. 321.

${ }^{5}$ H. Więckowska, Grycz Józef..., s. 300; H. Więckowska, I. Treichel, Grycz Józef..., s. 69; B. Horodyski, Józef Grycz, s. 3; W. Pociecha, Józef Grycz..., s. 321; I. Barowa, Józef Grycz - bibliotekarz z zamiłowania, „Biuletyn Miesięczny (Biblioteka Jagiellońska)” 1954, R. 6, nr 10-11, s. 3.

${ }^{6}$ H. Więckowska, Grycz Józef..., s. 300; H. Więckowska, I. Treichel, Grycz Józef..., s. 69; B. Horodyski, Józef Grycz, s. 3-4. 
z przedstawiciela Ministerstwa Wyznań Religijnych i Oświecenia Publicznego, po dwóch reprezentantów bibliotek naukowych i dwóch delegatów warszawskiej Biblioteki Publicznej ${ }^{7}$. Artykuł wywołał dyskusję w polskich środowiskach bibliotekarskim i naukowym ${ }^{8}$.

W 1925 roku Grycz ogłosił drukiem efekt pracy nad kolekcją czytelni Biblioteki Jagiellońskiej, publikując Katalog biblioteki podręcznej czytelni oraz biura katalogowego. Skatalogowane zbiory podzielił na dziesięć działów: religia i teologia, filozofia, matematyka i nauki przyrodnicze, medycyna, geografia, historia, archeologia i sztuka, prawo i nauki społeczne, filologia, encyklopedia i bibliografia. W ramach głównych działów wyróżnił szczegółowe poddziały. Publikacje z dziedziny pedagogiki uwzględnił jako część działu filozofia. Encyklopedie i bibliografie pogrupował następująco: encyklopedie, biografie i schematyzmy, bibliografie ogólne, bibliografie stosowane, bibliotekarstwo, drukarstwo, księgarstwo, wydawnictwa zbiorowe i ciągłe. Katalog uzupełnił indeksem. Przedmowę napisał dyrektor Biblioteki Jagiellońskiej, Fryderyk Papée?.

$\mathrm{Z}$ tego samego roku pochodzi inna publikacja Grycza, Przewodnik dla korzystajacych $z$ bibliotek oraz spis dzieł pomocniczych, adresowana przede wszystkim do studentów ${ }^{10}$. Autor podkreślił w krótkim wstępie do przewodnika, iż: „Jednym z zadań biblioteki jest współdziałanie ze szkołą w nauce i kształceniu ogólnym czy fachowym przez gromadzenie i odpowiednie przysposabianie potrzebnego materiału naukowego". Zadanie uczelni i szkół w zakresie edukacji czytelniczej określił następująco: „[... ] szkoła powinna uczniów wdrażać do racjonalnego i wydatnego eksploatowania zasobów bibliotecznych, zapoznając ich z urządzeniami bibliotek, tak jak powinna być przedmiotem nauki metodyka pracy umysłowej"11. W poradniku wyjaśnił zadania bibliotek i ich organizację. Przedstawił podstawowe wiadomości o książce. Pisał o gatunkach książek i rodzajach literatury, uwzględniając podział na publikacje naukowe oraz beletrystyczne i niebeletrystyczne. Skupił się też na autorze, układzie treści, tytule, podziale zewnętrznym i warto-

7 J. Grycz, O polskie przepisy katalogowania, „Exlibris” 1924, t. 5, z. 6, s. 205-215 (artykuł opublikowany w Dziale krytycznym); Zob. też tenże, O polskie przepisy katalogowania, Kraków 1925 (odbitka z z. 6 „Exlibirisu” wytłoczona w Drukarni Narodowej w Krakowie w stu pięćdziesięciu egzemplarzach).

${ }^{8}$ B. Horodyski, Józef Grycz, s. 9.

9 Biblioteka Jagiellońska w Krakowie. Katalog biblioteki podręcznej czytelni oraz biura katalogowego, opracował J. Grycz, Kraków 1925.

${ }^{10}$ H. Więckowska, Grycz Józef..., s. 300.

${ }^{11} \mathrm{~J}$. Grycz, Przewodnik dla korzystających z bibliotek oraz spis dzieł pomocniczych, Kraków [1925] (wstęp podpisany J.G., datowany: „Kraków, we wrześniu 1925”), s. V. 
ści książki. Wyjaśnił zasady opisu bibliograficznego. Ważna część publikacji dotyczyła korzystania z biblioteki. Zawierała wiadomości o katalogowaniu, cytowaniu bibliograficznym, czytelniach i wypożyczalni. Grycz podzielił spis dzieł, pomocnych w korzystaniu ze zbiorów bibliotecznych na bibliografie polskie oraz obcojęzyczne ogólne i specjalne, katalogi książek, spisy anonimów i pseudonimów, skorowidze biograficzne, encyklopedie o treści ogólnej i specjalistycznej (powszechne i specjalne) oraz katalogi rękopisów. Spis ten dołączył do przewodnika. Encyklopedie specjalne wyróżnił w podziale na dziedziny wiedzy: teologię, filozofię, pedagogikę, prawo i nauki społeczne, nauki przyrodnicze, nauki stosowane, geografię, historię wraz z naukami pomocniczymi, językoznawstwo i literaturę. Uzupełnił przewodnik spisem ważniejszych księgozbiorów i archiwów polskich, wyliczając je pod uszeregowanymi alfabetycznie nazwami miast. W lekturze publikacji pomagał skorowidz alfabetyczny umieszczony na końcu ${ }^{12}$. Autor przewodnika występował z postulatem wprowadzenia w bibliotekach uniwersyteckich przysposobienia bibliotecznego dla studentów pierwszego roku ${ }^{13}$.

W 1926 roku Grycz powrócił do sprawy kodyfikacji przepisów katalogowania zbiorów bibliotecznych w RP, publikując pracę Porównanie polskich przepisów katalogowania. Zestawił w niej i przeanalizował instrukcje opracowane przez Edwarda Kuntzego, Rudolfa Kotulę, Wacława Borowego i Związek Bibliotekarzy Polskich. ${ }^{14}$ W konkluzji stwierdził:

Jak widać różnic [...] ani nie jest tak wiele, ani też nie są tak głębokie, żeby wykluczały możliwość dojścia do porozumienia. Najwięcej trudności będzie z przepisami dotyczącymi wyboru słowa porządkowego, a tu zwłaszcza z instrukcją Kotuli, która w stosunku do innych instrukcji przesunęła prawo wyboru słowa porządkowego na korzyść hasła rzeczowego. Z tym wszystkim mogą nasze istniejące już instrukcje dostarczyć wiele, w dużej mierze nawet

12 Tamże.

13 H. Więckowska, I. Treichel, Grycz Józef..., s. 69.

14 Porównanie polskich przepisów katalogowania, zestawił J. Grycz, Kraków 1926 (na s. 5 wydrukowana dedykacja: „Drugiemu Zjazdowi Bibliofilów Polskich w Warszawie przedkłada autor”). Grycz, studiując instrukcje, konsultował się z innymi bibliotekarzami. 2 września 1926 roku zwrócił się drogą listowną do Adama Łysakowskiego, opracowującego katalog rzeczowy zbiorów Biblioteki Uniwersyteckiej w Wilnie, z prośbą o informację na temat zasad prowadzonej pracy, zob.: Bibliotekarstwo polskie 1925-1951 w świetle korespondencji jego współtwórców, wyboru z listów Adama Łysakowskiego, Mariana Łodyńskiego, Józefa Grycza i Heleny Hleb-Koszańskiej dokonała, wstępem i przypisami opatrzyła M. Dembowska, Warszawa 1995, s. 203 (list J. Grycza do A. Łysakowskiego, Kraków, 2.09.1926). 
zupełnie gotowego materiału do ogólnopolskich przepisów, mogą posłużyć jako substrat do fachowej dyskusji, $\mathrm{w}$ tym też celu zostało przeprowadzone niniejsze porównanie.

Informował, iż przygotowuje dalszą pomoc dla redaktorów oczekiwanych ogólnopolskich przepisów, opracowując porównanie zagranicznych instrukcji katalogowania ${ }^{15}$.

Działalności macierzystej instytucji poświęcił artykuł Ostatnie dwudziestolecie Biblioteki Jagiellońskiej, zamieszczony w 1928 roku w „Przeglądzie Powszechnym" 16 .

$\mathrm{Na}$ początku października 1928 roku Józef Grycz został mianowany dyrektorem Biblioteki Kórnickiej. Przed nim książnicą kierował Władysław Pociecha. Grycz objął stanowisko w wyniku konkursu, w którym kandydowało siedem osób. Zarządzał biblioteką do 1930 roku. Jako dyrektor doprowadził do remontu lokalu oraz zreorganizował księgozbiór podręczny i prace katalogowe. Zapoczątkował wydawanie czasopisma „Pamiętnik Biblioteki Kórnickiej”, redagując pierwszy zeszyt, opublikowany w 1929 roku. ${ }^{17}$ Systematycznie wprowadzał nowoczesne metody pracy bibliotekarskiej. Urządził biura i pracownię wyposażoną w bibliotekę podręczną. Zatrudnił nowych pracowników, między nimi swą przyszłą żonę Alodię Kawecką. Prace biblioteczne rozpoczął od wydzielania druków z XVI i XVII wieku z ogólnego zasobu, dla którego wprowadzono numerus currens. Oprócz starodruków katalogowano z sukcesem rękopisy, m.in. średniowieczne. Podjęto na dużą skalę konserwację zbiorów. Nowy dyrektor zajmował się też powiększaniem kolekcji, głównie drogą kupna i pozyskując dary. Położył duży nacisk na udostępnianie, usprawniając je opracowanym przez siebie regulaminem. Nad korzystaniem ze zbiorów na miejscu znacznie dominowały wypożyczenia zamiejscowe z uwagi na trudny dojazd do położonego na uboczu Kórnika. Grycz, chcąc zintensyfikować działalność edytorską biblioteki, przekazał skład główny jej oferty wydawniczej do Księgarni Św. Wojciecha w Poznaniu. Księgarnia opublikowała katalog bibliotecznych wydawnictw naukowych, dzięki czemu systematycznie wzrastała sprzedaż ${ }^{18}$.

\footnotetext{
15 Porównanie polskich przepisów katalogowania..., s. 33.

16 Zob.: J. Grycz, Ostatnie dwudziestolecie Biblioteki Jagiellońskiej (1905-1926), „Przegląd Powszechny" 1928, R. 45, t. 177, s. 245-253 (nadbitka).

${ }^{17}$ H. Więckowska, Grycz Józef..., s. 300-301; H. Więckowska, I. Treichel, Grycz Józef.., s. 69.

18 Z. Kalisz, Józef Grycz w Bibliotece Kórnickiej, „Pamiętnik Biblioteki Kórnickiej” 1955, z. 5 (nadbitka), s. 166-168, 173; W. Pociecha, Józef Grycz..., s. 323-324.
} 
Grycz, kierując Biblioteką Kórnicką, opracował publikacje dotyczące jej historii i współczesnej działalności, wydrukowane w „Pamiętniku Biblioteki Kórnickiej”"19, „Przeglądzie Bibliotecznym”20 i w postaci broszurowej ${ }^{21}$. Pisząc na temat bieżącej działalności i planów Biblioteki Kórnickiej, omówił tymczasowy regulamin, przyjęty 9 stycznia 1928 roku przez Kuratorium fundacji Zakłady Kórnickie, do której należała biblioteka. Informował o modernizacji lokalu z punktu widzenia potrzeb bibliotekarzy i czytelników, przeprowadzonej konserwacji części zabytkowych pomieszczeń, toczących się pracach w zakresie katalogowania druków i rękopisów, przygotowaniu pierwszego tomu czasopisma naukowego. Podkreślił, iż opracowano tymczasowy regulamin dla osób zwiedzających zamek i dla korzystających z biblioteki. Bibliotekę Kórnicką nazwał „własnością Narodu”22. Zachęcając czytelników do odwiedzenia kórnickiego zamku, stwierdził, iż ten ośrodek kultury i nauki jest „dziełem wspaniałomyślnych Polaków”, wybitnie się przyczyniającym do „pomnożenia dobra kulturalnego narodu”23.

W 1929 roku, czyli jeszcze kierując Biblioteką Kórnicką, Grycz wydał Porównanie zagranicznych przepisów katalogowania, pracę, którą zapowiedział rok wcześniej, publikując zestawienie instrukcji polskich. Omówił w niej, porównał i zestawił $\mathrm{w}$ tablicach reguły pruskie, angloamerykańskie, francuskie, włoskie i czeskie ${ }^{24}$. Podkreślił, iż celem porównania jest, podobnie jak w przypadku publikacji z 1926 roku, dostarczenie materiału, który może pomóc w rozstrzygnięciu kwestii spornych przy omawianiu polskich zasad ${ }^{25}$.

Dyrektor Grycz odszedł z Zakładów Kórnickich, obejmując 1 stycznia 1930 roku stanowisko radcy i referenta do spraw bibliotek naukowych w Ministerstwie Wyznań Religijnych i Oświecenia Publicznego. Zaczął się odtąd zajmować całokształtem spraw bibliotecznych w kraju, mając na celu unowocześnienie polskiego bibliotekarstwa. Prowadził sprawy związane $\mathrm{z}$ organizacją Biblioteki Narodowej w Warszawie, powołanej formalnie

19 J. Grycz, Bibliotekarze kórniccy, Poznań 1929 (odbitka z „Pamiętnika Biblioteki Kórnickiej” 1929, z. 1).

${ }^{20}$ Tenże, Polityka Biblioteki Kórnickiej. Rzut oka w przeszłość i przyszłość, Kraków 1929 (osobne odbicie z „Przeglądu Bibliotecznego” 1929, R. 3, z. 2).

${ }_{21}$ Tenże, Zamek Kórnicki i jego zbiory, Poznań 1929.

${ }^{22}$ Tenże, Polityka Biblioteki Kórnickiej..., s. 7-10.

${ }^{23}$ Tenże, Zamek Kórnicki..., s. 25.

${ }_{24}$ Porównanie zagranicznych przepisów katalogowania, zestawił J. Grycz, Kraków 1929 (odbitka z „Silva Rerum” 1929 R. 4, zeszyt 619, wytłoczono w Drukarni W.L. Anczyca w Krakowie w 200 numerowanych egzemplarzach, nr 105) (na s. 5 - drukowana dedykacja: „Drugiemu Zjazdowi Bibliotekarzy Polskich w Poznaniu przedkłada autor").

25 Tamże, s. 9. 
w 1928 roku, podlegającej Departamentowi Nauki MWRiOP. We współpracy ze Stefanem Dembym pozyskał dla biblioteki w 1930 roku prowizoryczny lokal w budynku Wyższej Szkoły Handlowej, a następnie wspólnie z nim kierował książnicą do 1934 roku $^{26}$.

Wśród problemów, którymi Grycz zajmował się jako ministerialny radca oraz osoba prowadząca Bibliotekę Narodową, były sprawy związane ze szkoleniem zawodowym bibliotekarzy. W 1930 roku apelował w „Przeglądzie Bibliotecznym” o organizację kursów dla bibliotekarzy zatrudnionych w bibliotekach naukowych i oświatowych. Odwołał się do artykułu redaktora „Przeglądu”, Edwarda Kuntzego, będącego dyrektorem Biblioteki Jagiellońskiej, zamieszczonego wcześniej w tym samym czasopiśmie, krytykując autora za ograniczanie postulatu powołania kursów do pracowników książnic naukowych. Proponował, by organizować kursy nie tylko dla bibliotekarzy, ale też dla kandydatów do zawodu bibliotekarskiego. Szkolenie miało według niego dawać kursantom całokształt wiedzy i umiejętności zawodowych. Wykładom teoretycznym musiały odpowiadać prowadzone równolegle ćwiczenia praktyczne. Za najważniejszy przedmiot nauczania uznawał opracowanie katalogów. Do artykułu dołączył proponowany program kursu wraz z rozkładem godzin. Zachęcał czytelników do zabierania głosu w omawianej kwestii, podkreślając, iż „Sprawa wymaga [...] dyskusji i to w jak najszybszym tempie, gdyż czas nagli, a potrzeba wykształconych bibliotekarzy jest nader pilną”27. W tym samym numerze „Przeglądu Bibliotecznego" ukazała się wypowiedź Jana Muszkowskiego poświęcona zagadnieniom dotyczącym egzemplarza obowiązkowego ${ }^{28}$. Od 1931 roku Grycz był członkiem komisji egzaminacyjnej przeprowadzającej państwowe egzaminy bibliotekarskie ${ }^{29}$.

W omawianym okresie zamieścił na łamach „Przeglądu Bibliotecznego" obszerny artykuł Biblioteka Narodowa na drugim etapie działalności, w którym omówił osiągnięcia książnicy oraz zaprezentował stojące przed nią zadania. Podkreślił, iż najwłaściwszym miejscem dla Biblioteki Narodowej jest stolica państwa. Centralna książnica miała być instytucją na-

${ }^{26}$ H. Więckowska, Grycz Józef..., s. 301; H. Więckowska, I. Treichel, Grycz Józef, s. 69-70; B. Horodyski, Józef Grycz, s. 17-18; E. Kurdybacha, W centrum polskiego bibliotekarstwa, czyli Józef Grycz [w:] Twórcy nowoczesnego bibliotekarstwa polskiego, red. B. Kocowski, red. naukowy H. Więckowska, Wrocław 1974, s. 122.

27 J. Grycz, O kursy bibliotekarskie, „Przegląd Biblioteczny” 1930 R. 4, z. 2, s. 184-196. Zob. też m.in.: E. Kurdybacha, $W$ centrum..., s. 123-124.

${ }^{28}$ J. Muszkowski, W sprawie egzemplarza bibliotecznego, „Przegląd Biblioteczny” 1930, R. 4, z. 2, s. $182-183$.

${ }^{29}$ H. Więckowska, Grycz Józef..., s. 301. 
ukową, publiczną i państwową. Do podstawowych funkcji BN zaliczył obok gromadzenia, opracowania, konserwacji i udostępniania poloniców krajowych oraz obcych, rejestrację piśmiennictwa polskiego i dotyczącego Polski, a także wszystkich narodowości zamieszkałych na terenie państwa. Za pożądane metody gromadzenia uznawał egzemplarz obowiązkowy, racjonalnie prowadzony zakup, przyjmowanie zbiorów rewindykowanych i wymianę. O kwestiach związanych z egzemplarzem obowiązkowym pisał, iż „Ustawowe unormowanie tych spraw jest jednym $\mathrm{z}$ najpilniejszych postulatów bibliotekarstwa". Słusznie postulował, żeby biblioteki chroniły pozycje egzemplarza obowiązkowego jako archiwalne, a w przypadku tytułów cieszących się dużym zainteresowaniem ze strony czytelników, nabywały dodatkowe egzemplarze. Omówił program pracy Instytutu Bibliograficznego BN zajmującego się rejestracją piśmiennictwa. Uważał, iż instytut powinien prowadzić nie tylko bibliografię bieżącą, ale także uzupełniać lukę w informacjach bibliograficznych z czasów między Bibliografią polską Karola Estreichera a współczesnością. Jako bardzo pilne zadanie głównej biblioteki państwa określił tworzenie centralnego katalogu polskich książnic. Wśród osiągnięć $\mathrm{BN}$ wymienił pozyskanie zbiorów rapperswilskich, rozpoczęcie działalności przez Instytut Bibliograficzny i wydawanie „Przewodnika Bibliograficznego". Postulował usamodzielnienie BN jako instytucji państwowej poprzez usunięcie jej podległości wobec Departamentu Nauki i Sztuki Ministerstwa Wyznań Religijnych i Oświecenia Publicznego. Dotychczasowe dotacje na działalność ocenił jako niewystarczające. Informował o najnowszym zadaniu realizowanym przez bibliotekę, jakim było prowadzenie Biura Międzynarodowej Wymiany Wydawnictw przejętego z dniem 1 kwietnia 1931 roku od Ministerstwa Spraw Zagranicznych. Podsumowując swoje uwagi, wymienił najważniejsze postulaty: uchwalenie przez Sejm ustawy o egzemplarzu obowiązkowym i wydanie przez władze stosownego rozporządzenia wykonawczego, regulaminowe unormowanie udostępniania $\mathrm{w}$ bibliotekach egzemplarza obowiązkowego, zatwierdzenie statutu BN, zorganizowanie informacji o polonicach zagranicznych, przeprowadzenie na podstawie ustawy o ochronie zabytków przymusowego wcielania do zbiorów BN cennych księgozbiorów i materiałów bibliotecznych narażonych na zniszczenie, porozumienie między bibliotekami państwowymi w kwestii specjalizacji i polityki zakupów, zorganizowanie ogłaszania corocznych przybytków przez książnice państwowe. Stwierdził z żalem, iż „Żądanie własnego gmachu, powiększenia dotacji, pomnożenia etatów, chociaż uzasadnione i aktualne, nie mają w obecnej sytuacji państwowej żadnych widoków realizacji”, dodał jednak z nadzieją, że „[...] 
i w tych warunkach, jakie obecnie panują, Biblioteka Narodowa ma ambicję, aby rytm i wydajność pracy dostosować do górnych swych zadań i celów"30.

W lutym 1934 roku Józef Grycz otrzymał w ministerstwie funkcję kierownika referatu bibliotek naukowych ${ }^{31}$.

W tym samym roku wraz z Janem Muszkowskim wziął udział w dyskusji nad projektem ustawy bibliotecznej ${ }^{32}$. W numerze 37 „Pionu” zamieszczono obok siebie na jednej stronie artykuły obu bibliotekarzy i bibliologów, uzupełniając je nagłówkiem: „Ku ustawie bibliotecznej”. Muszkowski pisał w tekście zatytułowanym $\mathrm{Na}$ drodze o trudnej sytuacji polskich bibliotek. Za negatywny uznał fakt, iż akcja biblioteczno-oświatowa w kraju jest prowadzona głównie przez organizacje o charakterze społecznym, czerpiące środki finansowe ze składek członków i dobrowolnych datków ogółu, a tylko częściowo zasilana przez Wydział Oświaty Pozaszkolnej MWRiOP i niektóre ciała samorządowe. Trafnie uznał składki i dobrowolne wsparcie finansowe za niepewne źródło dochodów, podczas gdy organizacja bibliotek musi być prowadzona długofalowo i wymaga ciągłości. Przypominał, że w sytuacji trwającego kryzysu gospodarczego zmniejsza się liczba placówek bibliotecznych. Apelując do władz o rozwiązania ustawowe, stwierdzał: „Jedynym środkiem na zaradzenie temu jest ustawa biblioteczna”. Informował też o ustawach bibliotecznych przyjętych w Wielkiej Brytanii, USA, a w latach 1919-1927 w Czechosłowacji, Bułgarii, Danii, Belgii, Estonii i Finlandii. Podkreślił, że niski poziom oświaty wśród społeczeństwa będzie w dalszej perspektywie bardziej kosztowny niż wydatki na kulturę, naukę i edukację ${ }^{33}$. Grycz przytoczył w artykule noszącym tytuł $W$ oczekiwaniu następujące argumenty za przyjęciem ustawy i apelował do polskich władz o podjęcie stosownych postanowień ${ }^{34}$ :

Oczekują jej uświadomione (a należy się ona i nieuświadomionym) szerokie warstwy ludności, dla których biblioteka powszechna ma być rozbudową

${ }^{30}$ J. Grycz, Biblioteka Narodowa na drugim etapie działalności, „Przegląd Biblioteczny” 1931, R. 5, z. 2-4, s. 109-136. W 1932 r. ukazała się odbitka cytowanego artykułu, zob. tenże, Biblioteka Narodowa na drugim etapie działalności, odbitka z „Przeglądu Bibliotecznego” 1931, R. 5, z. 2-4, Kraków 1932.

${ }^{31}$ H. Więckowska, Grycz Józef..., s. 301; H. Więckowska, I. Treichel, Grycz Józef..., s. 70; Materiaty do stownika..., s. 32 .

${ }^{32}$ H. Więckowska, Grycz Józef..., s. 301; H. Więckowska, Muszkowski Jan (10 IV 1882 Warszawa - 29 I 1953 Łódź)..., s. 615.

33 J. Muszkowski, Na drodze, „Pion” 1934, R. 2, nr 37, s. 5.

${ }^{34}$ J. Grycz, W oczekiwaniu, tamże, s. 5-6. 
szkoły, chroniącą je od analfabetyzmu powrotnego i umożliwiającą [...] zdobywanie potrzebnych wiadomości i godziwą rozrywkę. Oczekują jej liczne rzesze «inteligencji», zwłaszcza żyjącej w mniejszych ośrodkach kulturalnych, czy zgoła na wsi, które wobec ogólnego stanu zubożenia nie są w stanie pożądanej książki nabyć! Potrzebom tym ma zadośćuczynić właśnie ustawa, która w jednym ze znanych mi projektów nakłada na gminy i powiatowe związki komunalne obowiązek zakładania i utrzymywania bibliotek publicznych celem udostępnienia obywatelom Rzeczpospolitej dobrej książki, a przez to podniesienia kultury, pogłębienia świadomości obywatelskiej i usprawnienia zawodowego.

W 1934 roku przedstawiono komisji sejmowej projekt organizacji sieci bibliotek publicznych opracowany przez Grycza. Jednak zrealizowano go dopiero w Polsce Ludowej na mocy Dekretu z dnia 17 kwietnia 1946 roku o bibliotekach i opiece nad zbiorami bibliotecznymi ${ }^{35}$.

Największym sukcesem Grycza w latach II RP było opracowanie oraz wprowadzenie w życie ujednoliconych reguł katalogowania alfabetycznego. W 1934 roku ukazała się praca Przepisy katalogowania w bibliotekach polskich. I. Alfabetyczny wykaz druków ${ }^{36}$. Reguły ogłoszone przez autora zostały wprowadzone w życie okólnikiem ministra wyznań religijnych i oświecenia publicznego jako obowiązujące w bibliotekach państwowych ${ }^{37}$. W przepisach zostały omówione zasady ogólne dotyczące katalogu alfabetycznego i jego zadań, jednostek katalogowych, typów kart katalogowych, opisu katalogowego i techniki sporządzania katalogu kartkowego. Unormowano redagowanie kart, skupiając się na haśle autorskim i tytułowym oraz formie hasła. Normalizując kwestie szczegółów wydawniczych, uwzględnianych przy katalogowaniu alfabetycznym, pisano o adresie wydawniczym, czyli miejscu i roku wydania druku, nakładcy i drukarzu oraz opisie zewnętrznym czyli informacjach na temat formatu, ilości stron, a także tablicach i innych dodatkach. Uwzględniono problem umieszczania sygnatur na kartach katalogu. Poza tym szczegółowo wyjaśniono zasady układu kart ${ }^{38}$.

Pracę zrecenzował w „Przeglądzie Bibliotecznym” autor pierwszego polskiego podręcznika do opracowania rzeczowego zbiorów Adam Łysakowski. Recenzent dostrzegł w dziele Grycza tak pozytywne strony, jak

${ }^{35}$ K. Więckowska, Grycz Józef..., s. 301. Treść przywołanego dekretu zostanie omówiona w dalszej części artykułu.

${ }^{36}$ Tamże; B. Horodyski, Józef Grycz., s. 21; [J. Grycz], Przepisy katalogowania w bibliotekach polskich. I. Alfabetyczny wykaz druków, Warszawa 1934.

37 W. Pociecha, Józef Grycz..., s. 325; H. Więckowska, Grycz Józef...., s. 301.

38 J. Grycz, Przepisy katalogowania... 
i niedoskonałości. Za słabość uznał nie zawsze poprawną stronę językową publikacji, powodującą niejasność sformułowania niektórych przepisów. Jako niesłuszne ocenił wprowadzenie szeregowania haseł według alfabetu łacińskiego zamiast polskiego, gdyż nie odpowiadały one nawykom czytelniczym. Uważał przepisy za zbyt skomplikowane dla pracowników mniejszych bibliotek, którzy często nie mają stosownego przygotowania zawodowego. Jednocześnie podkreślił z uznaniem, że praca Grycza to „Na terenie polskiej literatury bibliotekarskiej (...) monumentalne dzieło (...) ”. Postawił przed środowiskiem bibliotekarskim następujące zadanie:

Teraz w oparciu o gotową instrukcję staje się aktualna kwestia skodyfikowania z jednej strony na stopniu wyższym prawideł szczegółowego opisu bibliograficznego, a z drugiej - uproszczonego opisu katalogowego dla bibliotek mniejszych oraz dla katalogów „użytkowych”, podręcznych, centralnych, osobno wreszcie dla potrzeb księgarstwa ${ }^{39}$.

Grycz zabiegał w latach trzydziestych u władz RP o podwyższenie zarobków bibliotekarzy z książnic państwowych, wnioskując o traktowanie ich jako pomocniczych sił naukowych i umożliwienie awansów. Podejmował powyższe działania wspólnie z Dyrekcją Archiwów broniącą interesów archiwistów ${ }^{40}$.

Pod koniec okresu międzywojennego ogłosił publikację, w której proponował powołanie przy Bibliotece Narodowej krajowego centrum dokumentacji bibliotekarstwa, działającego we współpracy z Międzynarodowym Centrum Dokumentacji Bibliotekarstwa. Miała to być część światowej sieci, jakiej powołanie postulowano w 1937 roku na Światowym Kongresie Dokumentacji Powszechnej w Paryżu. Polskie centrum zajmowałoby się zbieraniem regulaminów i formularzy, prowadzeniem centralnego katalogu literatury bibliotekoznawczej i księgoznawczej oraz kartoteki biograficznej bibliotekarzy. Ponadto w jego kompetencjach byłaby także odpowiedzialność za bibliotekarskie słownictwo fachowe. Grycz przekonywał, iż „koordynacja potrzeb i sił" przyczyni się do usprawnienia pracy prowadzonej przez bibliotekarzy ${ }^{41}$.

39 A. Łysakowski, Przepisy katalogowania w bibliotekach polskich. I. Alfabetyczny katalog druków. Warszawa MCMXXXIV. Nakładem Biblioteki Narodowej. 8 0. S. XVIII, 101, „Przegląd Biblioteczny" 1934, R. 8, z. 1, s. 169-182.

${ }^{40}$ Bibliotekarstwo polskie 1925-1951..., s. 227 (list J. Grycza do A. Łysakowskiego, Warszawa, 19.12. 1934).

${ }^{41} \mathrm{~J}$. Grycz, O centrum dokumentacji bibliotekarstwa, Kraków 1938 (osobne odbicie z „Przeglądu Bibliotecznego" 1938, R. 12, z. 1), s. 3-6. 
Uczestniczył w działalności Związku Bibliotekarzy Polskich, będąc kolejno członkiem zarządów kół krakowskiego, poznańsko-pomorskiego i warszawskiego. Wchodził do Rady Związku. W 1927 roku należał do grona założycieli organu naukowego ZBP, czasopisma „Przegląd Biblioteczny”. W latach 1927-1928 był sekretarzem redakcji „Przeglądu” ${ }^{2}$.

Na początku okupacji hitlerowskiej pracował jako tłumacz w Zarządzie Miasta Warszawy. Uczestniczył w tajnym nauczaniu, prowadząc lekcje w konspiracyjnym gimnazjum Zgromadzenia Kupców. Od 29 lipca 1940 roku za zgodą polskiego podziemia był kierownikiem Biblioteki Narodowej, przekształconej w II Oddział Staatsbibliothek Warschau, oficjalnie niedostępnej polskim czytelnikom. Podlegał doktorowi Gustawowi Abbowi stojącemu na czele Głównego Zarządu Bibliotek Generalnej Guberni oraz referentowi od spraw bibliotek na Okręg Warszawski doktorowi Wilhelmowi Witte. Obydwaj niemieccy zarządcy byli z zawodu bibliotekarzami. Grycz organizował nielegalnie udostępnianie zbiorów i działał w kierunku ich ochrony przed zniszczeniem ${ }^{43}$. Stał na czele Zespołu Bibliotek stanowiącego część Działu Kultury Delegatury Rządu na Kraj ${ }^{44}$. Za jego pośrednictwem Tajna Organizacja Nauczycielska (TON) koordynująca nielegalne polskie nauczanie miała wpływ na środowiska bibliotekarskie w całym $\mathrm{kraju}^{45}$. Udostępniał polskie książki także na potrzeby tajnego nauczania akademickiego. Historyk literatury Julian Krzyżanowski wspominał, że dzięki Gryczowi wyniósł z biblioteki „kilka plecaków książek potrzebnych dla studentów" ${ }^{46}$. Kierownik BN współpracował z dyrektorem Muzeum Narodowego Stanisławem Lorentzem w zakresie ochrony ojczystego dziedzictwa kulturowego pod pozorem oficjalnych kontaktów służbowych ${ }^{47}$. Wolny czas poświęcał na pracę nad publikacjami, które wydrukowano po II wojnie światowej, w tym przyszłym podręcznikiem Bibliotekarstwo praktyczne $w$ zarysie. Pomagał materialnie polskim uczonym i artystom

${ }^{42}$ H. Więckowska, I. Treichel, Grycz Józef..., s. 70; H. Więckowska, Grycz Józef..., s. 301; Materiaty do stownika..., s. 32.

${ }^{43}$ H. Więckowska, I. Treichel, Grycz Józef..., s. 70; H. Więckowska, Grycz Józef..., s. 301; W. Sokołowska, W Bibliotece Uniwersyteckiej 1939-1944 [w:] Walka o dobra kultury. Warszawa 1939-1945. Ksiega zbiorowa, pod red. S. Lorentza, t. 1, Warszawa 1970, s. 285.

${ }^{44}$ S. Lorentz, W muzeum i gdzie indziej [w:] Walka o dobra kultury..., t. 1, s. 25; R. Przelaskowski, Wspomnienie o pracy w Bibliotece Publicznej m. st. Warszawy w okresie II wojny światowej [w:] Tamże, s. 374.

${ }_{45}$ Cz. Wycech, Z dziejów tajnej oświaty w latach okupacji 1939-1944, Warszawa 1964, s. 104.

${ }^{46} \mathrm{~J}$. Krzyżanowski, Dziwne losy książi w okupowanej Warszawie [w:] Walka o dobra kultury..., t. 1, s. 158.

${ }^{47}$ R. Jarocki, Sztuka i krew 1939-1945. Opowieść o ludziach i zdarzeniach, Warszawa 2012, s. 123. 
pozbawionym środków do życia, kupując od nich do przyszłych zbiorów bibliotecznych cenne rękopisy ${ }^{48}$. Należał do organizatorów i uczestników narad dotyczących odbudowy i rozwoju bibliotekarstwa w niepodległej Polsce. Jedno z zebrań dotyczyło projektowanych zmian w katalogowaniu alfabetycznym. Wśród uczestników dyskusji znaleźli się także m.in. Adam Łysakowski i Władysława Borkowska ${ }^{49}$.

Edward Assbury tak ocenił działalność prowadzoną przez Grycza od lipca 1940 roku do wybuchu powstania warszawskiego, której celem było zabezpieczenie warszawskich zbiorów bibliotecznych: "Jakiego nakładu energii wymagało prowadzenie tej akcji, ile trzeba było pokonać oporów, przełamać przeszkód, za cenę jakich zabiegów, starań i krzątaniny uzyskiwało się wreszcie, że ten czy inny księgozbiór wpłynął do Biblioteki Narodowej, o tym chyba najlepiej mógł powiedzieć żarliwy inicjator i niestrudzony patron tego przedsięwzięcia dr Józef Grycz, polski kierownik Biblioteki Narodowej" 50 .

Podczas Powstania Warszawskiego Grycz starał się zapewnić bezpieczeństwo zbiorom zgromadzonym w gmachu Biblioteki Narodowej na ul. Rakowieckiej ${ }^{51}$, strzegąc ich wspólnie z żoną Alodia Kawecką-Gryczową i bibliotekarzem dr Andrzejem Grodkiem. Prowadził dziennik, którego fragmenty opublikowano po wojnie. 16 października zanotował: „Rano przyszedł inż. Bykowski, proponując nam wstąpienie do RGO [Rady Głównej Opiekuńczej], co dałoby nam legitymacje i opaski, uprawniające do poruszania się po mieście. Nie skorzystaliśmy z tego, bo w razie ewakuacji RGO musielibyśmy opuścić bibliotekę, czego chcemy uniknąć. Mówił, że Okólnik wypalony do tła, Zamoyscy też. Archiwum Główne i na Jezuickiej częściowo zburzone i wypalone. Łodyński, Bachulski - w Pruszkowie. Lorentz, Zachwatowicz też wyjechali. Tylko Biblioteki: Publiczna i Narodowa, jakby oazy, pozostały z ludźmi. Pono (...) Komisja Gestapo chce resztę zbiorów ewakuować. Bykowski też chce wyjechać. Co robić?... Chciałbym nawiązać kontakt z ludźmi i ewentualnie współpracować nad przyszłością bibliotekarstwa" ${ }^{52}$. Literaturoznawca i bibliotekarz Wacław Borowy zapisał

${ }^{48}$ H. Więckowska, I. Treichel, Grycz Józef..., s. 70; I. Barowa, Józef Grycz..., s. 5; A. Kawecka-Gryczowa, Ochrona zbiorów Biblioteki Narodowej, [w:] Walka o dobra kultury..., t. 1, s. 206, 211.

${ }_{49}$ W. Sokołowska, W Bibliotece Uniwersyteckiej..., s. 315.

${ }^{50}$ E. Assbury, Losy księgozbiorów warszawskich zabezpieczonych w Bibliotece Narodowej w latach 1940-1944 [w:] Walka o dobra kultury..., t. 1, s. 271-272.

${ }^{51}$ H. Więckowska, I. Treichel, Grycz Józef..., s. 70; W. Pociecha, Józef Grycz..., s. 327.

52 J. Grycz, Dzienniczek z okresu powstania warszawskiego 1944 roku [w:] Z zagadnień teorii i praktyki..., s. 21. Leon Bykowski i Marian Łodyński byli bibliotekarzami warszawskich bibliotek, Aleksy Bachulski archiwistą, a Jan Zachwatowicz generalnym konserwatorem Warszawy, 
w dzienniku pod datą „Milanówek, 22 X 1944”: „Grycz, jego żona i jeszcze jeden bibliotekarz (Grodek) przebywają ciągle w bibliotece Narodowej na Rakowieckiej”53. Dyrektor Lorentz, wspominając wyjazd z Warszawy po powstaniu, napisał: „Gdy 16 października 1944 r. po południu żandarmeria niemiecka nas wywoziła, obejrzałem się na gmach Muzeum Narodowego, przekonany, że widzę go po raz ostatni. Przecież w moich oczach w dniach 14, 15 i 16 października żołnierze rozstawiali w podziemiach skrzynki z dynamitem - w następnych zaraz dniach gmach miał być wysadzony w powietrze. Przejeżdżaliśmy pustymi ulicami w zupełnej ciszy, przez ruiny miasta, które też miały zniknąć, by na miejscu, gdzie była Warszawa, pozostała tylko pustynia. Wydawało mi się, że my ostatni z mieszkańców miasta opuszczamy Warszawę. Tak jednak nie było. Dr Grycz do 25 października dotrwał w Bibliotece Narodowej, a z Biblioteki Publicznej ostatnich 7 pracowników wywieziono dopiero 25 listopada" ${ }^{4} .25$ października dyrektor Grycz został wraz z dwoma pozostałymi osobami czuwającymi nad zbiorami przy Rakowieckiej: żoną i Andrzejem Grodkiem, popędzony przez patrol żandarmerii niemieckiej do obozu w Pruszkowie ${ }^{55}$.

Od 16 listopada Grycz uczestniczył w tzw. akcji pruszkowskiej, kierując ewakuacją z Warszawy księgozbiorów bibliotecznych ocalałych po powstaniu i opiekując się magazynem książek wywiezionych do Pruszkowa ${ }^{56}$. Z ramienia Niemców ewakuację nadzorował Gustaw Abb, który zgodnie z relacją Tadeusza Makowieckiego zagarnął część zbiorów, w tym rękopiśmienne zapisy nut wykonane przez nauczyciela Fryderyka Chopina, Józefa Elsnera, i wysłał je lub osobiście wywiózł do Niemiec ${ }^{57}$.

Tamże, s. 21 (przypisy nr 8 i 10). Cytowany dziennik został wydrukowany także w tomie Walka o dobra kultury, zob. tenże, Dzienniczek z okresu powstania warszawskiego $1944 \mathrm{r}$. [w:] Walka o dobra kultury..., t. 1, s. 248-256.

${ }^{53}$ W. Borowy, Z zapisek Borowego (1944-1945), opracowała Z. Stefanowska [w:] Walka o dobra kultury..., t. 1, s. 179.

${ }^{54}$ S. Lorentz, $W$ muzeum..., s. 84-85.

55 J. Grycz, Dzienniczek... [w:] Z zagadnień teorii i praktyki..., s. 21; A. Kawecka-Gryczowa, Ochrona zbiorów..., s. 221.

${ }^{56}$ H. Więckowska, I. Treichel, Grycz Józef..., s. 70; H. Więckowska, Grycz Józef..., s. 301; S. Lorentz, W muzeum..., s. 97; S. Herbst, Relacja [w:] Walka o dobra kultury..., t. 1, s. 137; Cz. Gutry, Pamiętnik [w:] Walka o dobra kultury..., s. t. I, s. 37-39 (lista osób biorących udział w akcji pruszkowskiej); M. Łodyński, Pruszkowska akcja zabezpieczania warszawskich zbiorów bibliotecznych [w:] Walka o dobra kultury..., t. 1, s. 266-282.

${ }_{57}$ T. Makowiecki, W obronie zbiorów bibliotecznych. Wspomnienie z 1944 r. [w:] Walka o dobra kultury..., t. 1, s. 258. 
W dniu wyzwolenia Warszawy spod okupacji hitlerowskiej, 17 stycznia 1945 roku, bibliotekarze podjęli decyzję o powrocie do miasta ${ }^{58}$. Dyrektor wrócił do Biblioteki Narodowej 2 lutego. Po dwóch miesiącach, na początku kwietnia 1945 roku, został wizytatorem w Wydziale Bibliotek Ministerstwa Oświaty. Kierował zabezpieczaniem księgozbiorów, przy którym stosowano się do zasad, jakie przedstawił w broszurze Wskazówki dla prowadzacych akcję zabezpieczania bibliotek i zbiorów bibliotecznych ${ }^{59}$. Opracowując ją, uwzględnił sprawy zabezpieczenia oraz odbudowy bibliotek szkolnych i powszechnych (publicznych), a także zabytkowych i naukowych. Podał zasady fachowego zabezpieczania, porządkowania, inwentaryzacji i opisu zbiorów. W przypadku pozycji zabytkowych zalecał poświęcenie szczególnej uwagi i troski drukom z XV-XVIII wieku i wszelkim rękopisom, szczególnie polonicom, czyli materiałom w języku polskim, wytworzonym w Polsce, stworzonym przez polskich autorów, względnie dotyczącym „spraw polskich" ${ }^{60}$. Wskazówki podsumował, podkreślając, iż „W ten sposób, usuwając lub łagodząc straty i szkody wyrządzone naszemu bibliotekarstwu przez wojnę, równać się będzie już także i torować drogi do jego nowej, planowej organizacji" 61 .

W odbudowie i organizacji polskich bibliotek pomagał podręcznik i zarazem poradnik Bibliotekarstwo praktyczne $w$ zarysie, przygotowywany przez Grycza w czasie okupacji, a wydany w 1945 roku przez Spółdzielnię Wydawniczą Czytelnik ${ }^{62}$. Autor stwierdził w Posłowiu, że praca z pewnością wymaga uzupełnień i udoskonalenia. Tłumaczył, iż pisząc ją w okresie okupacji, od listopada 1942 roku, nie miał dostępu do potrzebnych książek i opracowywanych wcześniej przez ponad dwadzieścia pięć lat notatek, bowiem zaginęły one w czasie wojny. Wykończenie przypadło na okres najtrudniejszy, kiedy Grycz był „na posterunku” w Bibliotece Narodowej w czasie powstania warszawskiego. Ukończył rękopis 19 września 1944 roku. Udało mu się go uratować i zabrać do obozu w Pruszkowie. Stale miał go przy sobie podczas przymusowych wędrówek. W Posłowiu podkreślił, że konieczność szybkiego opublikowania podręcznika dla powojennych bibliotekarzy nie

${ }^{58}$ A. Kawecka-Gryczowa, Ochrona zbiorów..., s. 232.

${ }^{59}$ H. Więckowska, I. Treichel, Grycz Józef.., s. 70; H. Więckowska, Grycz Józef..., s. 301; B. Horodyski, Józef Grycz, s. 33; W. Pociecha, Józef Grycz..., s. 327-328.

${ }^{60}$ Zob.: Wskazówki dla prowadzacych akcję zabezpieczania bibliotek i zbiorów bibliotecznych, opracował J. Grycz, Warszawa, Poznań 1945.

${ }^{61}$ Tamże, s. 16.

${ }^{62}$ J. Grycz, Bibliotekarstwo praktyczne w zarysie. Podręcznik i poradnik, Warszawa 1945. 
pozwoliła na dopracowanie tekstu ${ }^{63}$. W przedmowie Od autora określił jako głównych adresatów dzieła nowych pracowników, rozpoczynających pracę w zawodzie w bibliotekach oświatowych i naukowych wraz z kończącą się wojną $^{64}$. W kolejnych rozdziałach dał przegląd wszystkich zagadnień związanych z bibliotekarstwem, od podstawowych pojęć, przez sprawy lokalu bibliotecznego, gromadzenia, ewidencji, katalogowania, przechowywania i udostępniania zbiorów po kwestię kierownictwa i administracji biblioteki oraz problemy dotyczące zbiorów specjalnych: rękopisów, starodruków, kartografii, muzykaliów i zbiorów graficznych ${ }^{65}$. Uwagi wstępne oraz dotyczące ogólnych zasad organizacji przestrzeni bibliotecznej i metodyki pracy bibliotekarskiej cechuje stała aktualność. Podręcznik autorstwa Józefa Grycza może być wzorem dla autorów literatury fachowej ze względu na bardzo przystępny, plastyczny język wykładu. Drugie wydanie wyszło sześć lat po pierwszym, w 1951 roku $^{66}$.

Bibliotekarstwo praktyczne zrecenzowała dla „Przeglądu Bibliotecznego” Helena Hleb-Koszańska. Uznała publikację za w pełni zaspokajającą potrzeby pracowników bibliotek oświatowych, wprowadzającą czytelników jednocześnie do bibliotekarstwa naukowego poprzez zasygnalizowanie problematyki zbiorów specjalnych. Dostrzegła w opracowaniu także liczne niedociągnięcia, czemu dała wyraz, krytykując układ treści oraz poddając w wątpliwość trafność wybranych porad i niektórych użytych terminów ${ }^{67}$.

W 1945 roku Grycz wziął udział w dyskusji dotyczącej państwowych przepisów normujących zadania oraz sytuację prawną i organizacyjną bibliotek. Omawiając projekt rozwiązań ustawowych, podkreślił, że w Polsce ma powstać ogólnokrajowa sieć bibliotek, utrzymywanych przez państwo lub związki publiczno-prawne, a naczelny nadzór nad bibliotekami i zbiorami bibliotecznymi będzie sprawowało Ministerstwo Oświaty. Jako zadanie kadry zarządzającej i pracowników książnic naukowych określił ustalenie charakteru zakresu działania bibliotek w myśl postulatu specjalizacji. Informował o budowie sieci publicznych bibliotek naukowych specjalnych, m.in. o organizacji Głównej Biblioteki Lekarskiej tworzonej z ramienia Ministerstwa Zdrowia. W kwestii bibliotek szkolnych tłumaczył, że in-

${ }^{63}$ J.G. [J. Grycz], Posłowie [w:] J. Grycz, Bibliotekarstwo praktyczne w zarysie..., s. 6.

${ }^{64}$ Od autora [w:] Tamże, s. 5-6.

${ }^{65} \mathrm{~J}$. Grycz, Bibliotekarstwo praktyczne w zarysie...

${ }^{66}$ H. Więckowska, I. Treichel, Grycz Józef..., s. 71; H. Więckowska, Grycz Józef..., s. 301.

${ }^{67}$ H. Hleb-Koszańska, Grycz Józef: Bibliotekarstwo praktyczne w zarysie. Podręcznik i poradnik (Warszawa). Spółdzielnia Wydawnicza Czytelnik 1945 (Drukarnia Narodowa w Krakowie), str. 232, „Przegląd Biblioteczny” 1946, R. 14, s. 28-44. 
tencją ustawodawcy jest skupienie się przede wszystkim na umożliwianiu czytelnikom dostępu do podręczników i lektur, zaś zaspokajaniem potrzeb czytelniczych ogólnych, szczególnie rozrywkowych, winny się zajmować biblioteki publiczne. Przypominał o konieczności zapewnienia im wyszkolonych nauczycieli bibliotekarzy. Postulował, by w samorządzie terytorialnym stopnia gminnego, powiatowego i wojewódzkiego pracowali referenci do spraw bibliotek. Władze lokalne i regionalne miały być wspierane także przez komitety biblioteczne ${ }^{68}$. Wydział Bibliotek opracował z udziałem Grycza projekt ustawy ${ }^{69}$.

Stosowne prawo wprowadzono w następnym roku, jednak nie ustawą, ale Dekretem z dnia 17 kwietnia 1946 roku o bibliotekach i opiece nad zbiorami bibliotecznymi. W części drugiej dekretu podano zasady organizacji ogólnokrajowej sieci bibliotek publicznych, będące realizacją wniosków Grycza $\mathrm{z}$ lat trzydziestych. Sieć tworzyły biblioteki powszechne, szkolne i naukowe, natomiast stanowiącą jej część sieć publicznych bibliotek powszechnych tworzyły biblioteki gminne (miejskie i wiejskie), powiatowe i wojewódzkie. Działalność placówek stopnia powiatowego i wojewódzkiego polegała na pomocy organizacyjnej i instruktorskiej jednostkom $z$ terenu danego powiatu lub województwa. Bibliotekom publicznym miast wojewódzkich zlecono rolę książnic regionalnych, gromadzących piśmiennictwo i inne dokumenty odnoszące się do swojego obszaru. Do zakładania i utrzymywania publicznych bibliotek samorządowych zobowiązano właściwe związki samorządowe, a obowiązek organizacji i prowadzenia publicznych bibliotek naukowych wzięło na siebie państwo. Samorządowa biblioteka publiczna mogła być zlikwidowana tylko za zgodą ministra oświaty, podjętą w porozumieniu $\mathrm{z}$ ministrem administracji publicznej. Powyższy dekret wszedł w życie 18 czerwca 1946 roku i obowiązywał do 1968 roku $^{70}$, kiedy uchwalono ustawę o bibliotekach, zastąpioną następnie ustawą o bibliotekach z 1997 roku.

Józef Grycz odniósł się do postanowień dekretu w pierwszym powojennym roczniku „Przeglądu Bibliotecznego”, reaktywowanego w 1946 roku. Wypowiedział pogląd, iż w związku z uchwaleniem dekretu i przejęciem przez państwo całokształtu spraw związanych z książką, należało przekształcić Wydział Bibliotek Ministerstwa Oświaty z komórki urzędowo-administracyjnej w organizacyjno-fachową, wyposażoną w stosowne uprawnienia,

${ }^{68}$ J. Grycz, Co wnosi polska ustawa biblioteczna?, „Bibliotekarz” 1945, R. 12, nr 1, s. 4-5.

${ }^{69}$ B. Horodyski, Józef Grycz, s. 34.

70 Dekret z dnia 17 kwietnia 1946 o bibliotekach i opiece nad zbiorami bibliotecznymi (Internetowy System Aktów Prawnych, Dziennik Ustaw 1946 nr 26 poz. 163) [online], [dostęp: 16.04.2013]. Dostępny w WWW: http://www.sap.sejm.gov.pl/DetailsServlet?id=WDU19460260163. 
środki i profesjonalny personel. Określił jako zdobycze bibliotekarstwa powołanie w ramach ministerstwa Naczelnej Dyrekcji Bibliotek oraz utworzenie Państwowego Instytutu Książki, prowadzącego działalność naukowo-badawczą i instrukcyjno-metodyczną. Informował o pracach w zakresie rejestracji strat poniesionych przez polskie biblioteki w czasie wojny. Pisał z nadzieją, że osiągnięcia „akcji bibliotecznej” powinny być rękojmią dalszych pozytywnych wyników prowadzonych działan ${ }^{71}$.

W 1946 roku ukazało się pierwsze wydanie skróconej wersji przepisów katalogowania alfabetycznego z 1934 roku, opracowane przez Grycza wspólnie z Władysławą Borkowską ${ }^{72}$. Recenzja Jana Kossonogi pojawiła się w „Przeglądzie Bibliotecznym”73.

Z dniem 1 kwietnia 1946 autor przepisów został dyrektorem Naczelnej Dyrekcji Bibliotek. Powierzoną funkcję pełnił do czasu objęcia 1 marca 1949 stanowiska wicedyrektora Biblioteki Narodowej ${ }^{74}$.

W schyłkowym okresie działalności Grycz opublikował prace bibliologiczne dotyczące historii książki i bibliotek. W 1949 roku Spółdzielnia Wydawnicza Chłopski Świat wydała książkę popularnonaukową Historia bibliotek $w$ zarysie, liczącą niecałe sto stron. Autor omówił dzieje bibliotek na świecie od starożytności po XX wiek oraz w Polsce od średniowiecza do pierwszych lat po II wojnie światowej. Pisząc o historii najnowszej, poświęcił część pracy bibliotekarstwu radzieckiemu. Dowodził tendencyjnie, iż w Związku Radzieckim „Do [...] roli służenia interesom narodu oraz ideowego wychowania mas w duchu teorii Marksa i Lenina przystosowana jest organizacja i działalność bibliotek”. Do „interesów narodu” zaliczył „walkę $\mathrm{z}$ analfabetyzmem i ciemnotą", przypominając, iż idzie ona w parze ze „Zwalczaniem wrogów nowej rzeczywistości”75. W przedmowie zacytował fragment przemówienia prezydenta Bolesława Bieruta z 1947 roku zawierający uwagę o konieczności upowszechniania w naszym kraju książek „tanich, dobrych i dostępnych dla najszerszych mas”, podkreślając, że jest to jedno z zadań „nowej Polski”76.

${ }^{71}$ J. Grycz, Problemy biblioteczne obecnej doby, „Przegląd Biblioteczny” 1946, R. 14, s. 4-24.

72 Zob.: Skrócone przepisy katalogowania alfabetycznego. Z przepisów katalogowania w bibliotekach polskich. I. Alfabetyczny wykaz druków, wybrali i opracowali J. Grycz, W. Borkowska, Warszawa 1946.

${ }^{73}$ J. Kossonoga, Polska instrukcja katalogowa, „Przegląd Biblioteczny” 1946, R. 14, s. 48-58.

${ }^{74}$ H. Więckowska, Grycz Józef..., s. 301; B. Horodyski, Józef Grycz, s. 37; W. Pociecha, Józef Grycz..., s. 329.

75 J. Grycz, Historia bibliotek w zarysie, Warszawa 1949, s. 56.

${ }^{76}$ J.G. [J. Grycz], Przedmowa [w:] Tegoż, Historia bibliotek..., s. 5. 
Po dwóch latach Wydawnictwo Ossolineum ogłosiło podręcznik $Z$ dziejów i techniki książki, napisany przez Grycza, który zgodnie z intencją autora miał być jednocześnie pracą popularnonaukową. Bibliolog podał wiadomości o powstaniu i rozwoju pisma oraz materiałów i narzędzi pisarskich od czasów starożytnych, historii książki rękopiśmiennej i drukowanej, ilustracjach i zdobnictwie, sztuce introligatorskiej oraz wytwarzaniu i rozpowszechnianiu książek. Doprowadził wykład do okresu Polski Ludowej. Fakty historyczne uzupełnił stronniczymi interpretacjami obowiązującymi $\mathrm{w}$ okresie stalinizmu. Jeden z przykładów to opis historycznego tła rozwoju drukarstwa $\mathrm{w}$ dobie reformacji. Wojny chłopskie w Niemczech zaliczono do nurtu plebejskiego, protestantyzm uznano za kierunek mieszczański i mieszczańsko-drobnoszlachecki, popierany ze względów politycznych przez część feudałów, a jeden z nurtów protestantyzmu, kalwinizm, zakwalifikowano jako „zdecydowanie burżuazyjny” "77. Do książki dołączono liczne sugestywe czarno-białe ilustracje ${ }^{78}$.

Podręcznik został zrecenzowany przez Jana Muszkowskiego w „Przeglądzie Bibliotecznym”. Recenzent nie tylko dokonał oceny najnowszej publikacji Grycza, ale także omówił jego wcześniejsze dzieła, poczynając od katalogu księgozbioru podręcznego czytelni głównej Biblioteki Jagiellońskiej wydanego w 1925 r. Uzasadnił zastosowany zabieg, tłumacząc:

Pragnąłem [...] scharakteryzować pokrótce najważniejszą część dorobku piśmienniczego Autora dla wiadomości wchodzącego w życie pokolenia pracowników książki, ponieważ tak łatwo zapomina się o swoich poprzednikach. Bez względu bowiem na takie czy inne wątpliwości lub zastrzeżenia, jakich nie może uniknąć żadne dzieło ludzkie, zwłaszcza w okresach rewolucyjnych przewrotów, omówione powyżej prace Józefa Grycza, którym towarzyszyła stale owocna działalność praktyczna na kilku poważnych stanowiskach, znaczą wielki krok na drodze rozwoju księgarstwa, samowiedzy bibliotekoznawstwa polskiego i techniki bibliotecznej, jako że posuwały się zawsze po linii postępu nowej wiedzy zawodowej, stwarzając solidny fundament dla dalszych badań i studiów.

Wielkie uznanie dla dorobku autora nie przeszkodziło Muszkowskiemu w przyjęciu krytycznej postawy wobec części recenzowanej publikacji. Przekonywał, że Grycz niesłusznie traktuje ilustrowanie i zdobienie książek

\footnotetext{
77 J. Grycz, Z dziejów i techniki książki, Wrocław 1951, s. 5, 57.

78 Tamże, s. 173-271.
} 
jako dwie odmienne czynności. Argumentował, iż ilustracje faktycznie często tylko uzupełniają i objaśniają tekst, a zdobienia służą celom estetycznym, jednak zdarza się, choćby w przypadku edycji literatury pięknej, że uplastyczniają na równi z tekstem wizję artystyczną ${ }^{79}$.

Józef Grycz był także autorem, względnie współautorem, innych prac z dziedziny historii książki ${ }^{80}$.

W 1953 roku wspólnie z Emilią Kurdybachą wydał podręcznik Bibliografia $w$ teorii i praktyce ${ }^{81}$. Współautorka wspominała później pracę nad książką $\mathrm{w}$ artykule poświęconym swemu mistrzowi ${ }^{82}$. Z tego samego roku pochodzi skrypt Biblioteka jako teren pracy bibliotekarza opracowany dla Państwowego Kursu Bibliotekarskiego ${ }^{83}$.

Pod koniec życia Grycz wydrukował pracę analogiczną do jednej ze swoich pierwszych publikacji, Przewodnika dla korzystających $z$ bibliotek z 1925 roku. Była to broszura Chodźmy do biblioteki. Poradnik dla czytelników, opublikowana w 1953 roku, adresowana do masowego odbiorcy. Autor uczył czytelników korzystania z bibliotek i ich zbiorów oraz zasad i techniki sporządzania notatek z lektury ${ }^{84}$.

Józef Grycz zmarł 23 października 1954 roku w Warszawie wskutek długotrwałej choroby, będąc $\mathrm{w}$ pełni sił twórczych ${ }^{85}$, niecałe dwa lata po Janie Muszkowskim zmarłym 29 stycznia 1953 roku w Łodzi ${ }^{86}$.

Władysław Pociecha napisał o Gryczu we wspomnieniu zamieszczonym w „Pamiętniku Biblioteki Kórnickiej” na 1955 rok, że: „Pamięć o tym szlachetnym człowieku i znakomitym bibliotekarzu przetrwa nie tylko wśród licznego grona jego kolegów i przyjaciół, ale także wśród ogromnych rzesz

${ }^{79}$ J. Muszkowski, Józef Grycz: Z dziejów i techniki książki. Wrocław 1951. Wyd.[awnictwo] Zakł. [adu] Narodowego im. Ossolińskich. 80 [stron] tekst[u], ryciny [na] s. 173- 221, „Przegląd Biblioteczny" 1952, R. 20, z. 2-3, s. 251-258.

${ }^{80}$ Zob.: J. Grycz, Krótki zarys historii książki i bibliotek, wydanie drugie poszerzone do druku przygotowała A. Kawecka-Gryczowa; J. Grycz, A. Gryczowa, Historia książki i bibliotek w zarysie, wydanie drugie, przejrzane i uzupetnione, Warszawa 1964. Pierwsze wydanie Krótkiego zarysu historii książki i bibliotek ukazało się w 1954 r. jako skrypt dla Państwowego Kursu Bibliotekarskiego, zob.: H. Więckowska, Grycz Józef..., s. 301.

${ }^{81}$ Zob.: J. Grycz, E. Kurdybacha, Bibliografia $w$ teorii i praktyce oraz wykaz ważniejszych bibliografii i dzieł pomocniczych, Warszawa 1953.

${ }_{82}$ E. Kurdybacha, $W$ centrum..., s. 129-130.

${ }^{83}$ H. Więckowska, Grycz Józef..., s. 301.

${ }^{84}$ J. Grycz, Chodźmy do biblioteki. Poradnik dla czytelników, Warszawa 1953.

${ }^{85}$ H. Więckowska, I. Treichel, Grycz Józef.., s. 71; H. Więckowska, Grycz Józef..., s. 301; B. Horodyski, Józef Grycz, s. 39; W. Pociecha, Józef Grycz.., s. 320; I. Barowa, Józef Grycz..., s. 3.

${ }^{86}$ H. Więckowska, Muszkowski Jan (10 IV 1882 Warszawa - 29 I 1953 Łódź)..., s. 615; taż, Muszkowski Jan (1882-1953)..., s. 300. 
bibliotekarzy, czytelników i miłośników książki, dla których był najlepszym nauczycielem, doradcą i przewodnikiem" ${ }^{87}$. Autorka okolicznościowego artykułu zamieszczonego w „Biuletynie Miesięcznym Biblioteki Jagiellońskiej”, Irena Barowa, nazwała zmarłego „bibliotekarzem z zamiłowania”88.

Upamiętnienie zasług wybitnego bibliotekarza praktyka i rozwój bibliologii jako nauki mieli na celu redaktorzy księgi pamiątkowej $Z$ zagadnień teorii i praktyki bibliotekarskiej, poświęconej Gryczowi, a opublikowanej w 1961 roku w Ossolineum. Tom podzielono na cztery części. W pierwszej, upamiętniającej postać i dorobek zawodowy głównego bohatera pracy zbiorowej, znalazły się tekst z dzienniczka Grycza z czasu powstania warszawskiego, cytowany wyżej wielokrotnie popularyzatorski artykuł Bogdana Horodyskiego o Gryczu, a także bibliografia jego publikacji i notatek opracowana przez Emilię Kurdybachę. Trzy pozostałe części, służące rozwojowi nauki o książce i bibliotece, zawierają studia na temat organizacji i działalności bibliotek, historii bibliotek oraz dziejów książki. Dwa artykuły bibliotekoznawcze dotyczą Łodzi. Są to teksty Izabeli Nagórskiej i Jana Augustyniaka ${ }^{89}$.

Z przedstawionych wywodów należy wyciągnąć wniosek, że Józef Grycz łączył działalność praktyczną w dziedzinie bibliotekarstwa $\mathrm{z}$ refleksją bibliologiczną i bibliotekoznawczą, jednak był przede wszystkim bibliotekarzem, w przeciwieństwie do profesora Jana Muszkowskiego, w którego dorobku działalność naukowa, szczególnie prowadzona na Uniwersytecie Łódzkim, miała równie istotne znaczenie, co praca $\mathrm{w}$ zawodzie bibliotekarskim ${ }^{90}$. Grycz w przeciwieństwie do Muszkowskiego nie był uczonym, bowiem wszystkie jego publikacje mają charakter prac fachowych, popularnonaukowych, względnie są podręcznikami. Dotyczy to m.in. książek o tematyce bibliologicznej i z historii bibliotek, będących opracowaniami popularyzatorskimi i dydaktycznymi.

Działalność Grycza i Muszkowskiego powinna być wzorem dla osób opracowujących i realizujących programy kształcenia bibliologicznego na poziomie uniwersyteckim, bowiem w kształceniu w zawodach związanych z książką należy skupiać się przede wszystkim na kwestiach praktycznych, traktując teorię jako uzupełnienie podstawowych treści nauczania. To samo dotyczy nauk w mniejszym lub większym stopniu pokrewnych bibliologii, takich jak kulturoznawstwo i dziennikarstwo.

\footnotetext{
${ }^{87}$ W. Pociecha, Józef Grycz..., s. 331.

${ }_{88}$ I. Barowa, Józef Grycz..., s. 3-6.

${ }^{89} \mathrm{Z}$ zagadnień teorii i praktyki...

${ }^{90}$ H. Więckowska, Muszkowski Jan (10 IV 1882 Warszawa - 29 I 1953 Łódź)..., s. 615-616, taż, Muszkowski Jan (1882-1953)..., s. 298-300.
} 


\section{Abstract \\ Józef Grycz (1890-1954) - Practising librarian and bibliologist}

Józef Grycz, one of the most eminent librarians, significantly contributed to organizing libraries. In 1928-1930 he managed the Kórnik Library. Later he worked in the Ministry of Religious Denominations and Public Enlightenment, and was responsible for establishing the National Library. A proposal for organizing a network of public libraries, elaborated by Grycz, was brought to a parliamentary commission in 1934, yet it was implemented only during the times of the People's Republic of Poland. Most notably, in the times of the Second Republic Grycz developed unified rules for alphabetical catalogues which he then introduced throughout Poland. During the Nazi occupation he was the manager of the National Library, transformed into the Second Branch of Staatsbibliothek Warschau. Approved at this position by Polish underground resistance movement, he provided illicit access to and protected the library holdings.

The course book entitled Bibliotekarstwo praktyczne w zarysie (1945) written by Grycz provided foundations for the process of restoring Polish libraries. 